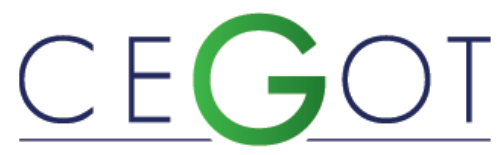

Centro de Estudos de Geografia e Ordenamento do Território
Geografia e Ordenamento do Território, Revista Eletrónica Centro de Estudos de Geografia e Ordenamento do Território http://cegot.org ISSN: 2182-1267

\title{
Construindo uma visão geral dos Projetos Especiais de Impacto Urbano de 20 Grau em
}

\section{Porto Alegre}

Building an overview of Special Projects of 2nd Degree Urban Impact in Porto Alegre

Referência: Fagundes, Júlia Ribes; Steigleder, Annelise Monteiro; Aguirre, Ana; Utzig, Elisa Escosteguy; Júlio, Roger de Oliveira Borges (2021). Construindo uma visão geral dos Projetos Especiais de Impacto Urbano de 2 은 Grau em Porto Alegre. Revista de Geografia e Ordenamento do Território (GOT), no 21 (Junho). Centro de Estudos de Geografia e Ordenamento do Território, p. 34-62, dx.doi.org/10.17127/got/2021.21.002

\section{RESUMO}

O presente artigo apresenta uma visão geral dos empreendimentos aprovados em Porto Alegre através do instrumento urbanístico Projetos Especiais de Impacto Urbano (P.E.), avaliando seus efeitos e impactos na cidade entre os anos de 2010 e 2019. Inicialmente, apresenta-se o conceito de "planejamento flexível" para explicar o tipo de planejamento praticado hoje na cidade e descreve-se o instrumento urbanístico com base no Plano 
Diretor. Na sequência, apresenta-se o quadro normativo dos P.E., realiza-se a descrição estatística e socioespacial dos empreendimentos e a leitura dos padrões socioeconômicos e urbanísticos das obrigações e contrapartidas resultantes da aplicação do instrumento. A pesquisa revela que, longe de se constituírem exceções, os Projetos Especiais se tornaram regra para os grandes empreendimentos realizados na cidade, compondo uma verdadeira onda de choque dos empreendimentos imobiliários de grande porte em Porto Alegre.

Palavras-chave: Projetos Especiais de Impacto Urbano; Plano Diretor; Planejamento Flexível; Porto Alegre.

\section{ABSTRACT}

This article presents an overview of the projects approved in Porto Alegre between the years 2010 and 2019, through the city's Special Projects of Urban Impact (PE) development instrument. The concept of "flexible planning" is presented to explain the type of planning practiced today and to describe the PE instrument as outlined in the Porto Alegre Master Plan. In the article, the PE normative framework is presented, followed by a statistical and socio-spatial description of the projects undertaken. The patterns regarding the socioeconomic and urban requirements are presented, as well as the community contributions or benefits that resulted from these projects. The research reveals that, rather than being exceptions, Special Projects have become the norm for large developments in Porto Alegre, resulting in a shock wave of large real estate developments in the city.

Keywords: Special Projects of Urban Impact; Master Plan; Flexible Planning; Porto Alegre.

\section{Introdução}

O objetivo deste artigo é apresentar uma visão geral dos empreendimentos aprovados em Porto Alegre através do instrumento urbanístico Projetos Especiais de Impacto Urbano (P.E.), avaliando seus efeitos e impactos na cidade entre os anos de 2010 e 2019. Esses projetos são definidos no Plano Diretor de Desenvolvimento Urbano Ambiental (PDDUA) como proposta de empreendimento ou atividade que, em função de sua natureza ou porte, não se encaixam no regime urbanístico vigente, necessitando análise diferenciada para potencial aprovação e exigindo a execução de contrapartidas, medidas mitigadoras e medidas compensatórias para o município.

Os Projetos Especiais, apesar de manifestarem-se em escala local, estão inseridos numa lógica global de planejamento e produção de cidades, onde destacam-se características como a competitividade entre cidades e flexibilização das normas urbanísticas para atrair novos investimentos. Neste contexto, a compreensão do instrumento urbanístico (Projetos 
Especiais) não exige o conhecimento prévio das práticas de planejamento brasileiras, senão a noção de fenômenos globais como o neoliberalismo e globalização.

Foram analisados os Projetos Especiais de $2^{\circ}$ grau, (P.E.2) $)^{1}$, visto que os P.E. de $1^{\circ}$ grau têm impacto menos expressivo e que, até este momento, não foram implementados na cidade P.E. de $3^{\circ}$ grau. O recorte temporal da pesquisa inicia na primeira revisão do PDDUA, ocorrida em 2010, quando o instrumento sofreu uma série de modificações, e termina com as informações obtidas, via Lei de Acesso à Informação, em agosto de 2019. A partir da descrição e análise urbanística, espacial e jurídica dos P.E.2, buscou-se construir uma visão de conjunto e de longo prazo sobre os efeitos e os impactos deste instrumento em Porto Alegre e contribuir com a discussão sobre a efetividade e os impactos deste instrumento de planejamento no desenvolvimento da cidade.

O artigo está estruturado em sete seções, sendo a primeira esta Introdução. Na segunda, apresenta-se o instrumento urbanístico ora em análise e o conceito de planejamento flexível, para explicar as práticas contemporâneas de planejamento urbano. A terceira seção apresenta o quadro normativo dos Projetos Especiais com a apresentação do regime jurídico previsto no Plano Diretor. Na quarta, compara-se o instrumento urbanístico de Porto Alegre com estratégias e instrumentos similares existentes em países europeus. A quinta parte descreve e analisa sócio espacialmente os P.E.2 aprovados, buscando apresentar uma visão geral do uso do instrumento e identificar padrões gerados ao longo dos dez anos de vigência do atual PDDUA. Na sexta seção, busca-se estabelecer padrões urbanísticos para as obrigações e contrapartidas. Finalmente, na seção sete, são apresentadas as considerações finais ponderando uma década de planejamento flexível aplicado na forma de projetos especiais e suas consequências para a cidade construída de Porto Alegre. Ao refletir sobre o papel do instrumento Projetos Especiais como uma política pública, verifica-se que a mesma deve ser revista em diversos aspectos para evitar o aumento da desigualdade socioeconômica e ambiental da cidade. Neste sentido, este artigo pretende ser uma contribuição para as políticas públicas da cidade, em particular para a revisão do atual PDDUA.

\footnotetext{
${ }^{1}$ A partir do nível de complexidade e abrangência do projeto, ele classifica-se em PE de $1^{\circ}, 2^{\circ}$ ou $3^{\circ}$ grau, em escala crescente de influência.
} 
A base de dados que subsidia esta pesquisa foi elaborada pelo Núcleo de Estudos e Pesquisa em Economia Urbana (NEPEU)² da Universidade Federal do Rio Grande do Sul e está composta por: (1) Tabela de empreendimentos que geraram Termos de Compromisso (T.C. $)^{3}$ entre empreendedor e Município com respectiva apresentação das obrigações urbanísticas e ambientais a serem executadas pelo empreendedor; (2) Termos de Compromisso firmados entre empreendedor e Município. A tabela foi obtida através da Lei de Acesso à Informação (Lei Federal 12.527/2011), mediante solicitação do NEPEU à Prefeitura Municipal de Porto Alegre, enquanto os Termos de Compromisso foram obtidos na página eletrônica da Procuradoria Geral do Munícipio. A confrontação dos Termos de Compromisso com as informações da tabela resultou na classificação de 91 empreendimentos como Projetos Especiais de $2^{\circ} \mathrm{Grau}$.

Quanto à metodologia, o trabalho baseou-se em pesquisa bibliográfica e de documentos legais, análise de dados secundários, interpretação jurídica e análise espacial. Através da pesquisa bibliográfica buscou-se caracterizar o planejamento urbano praticado no Brasil e no mundo nas últimas décadas, destacando-se o aspecto de flexibilização das normas urbanísticas. A análise da legislação, mais especificamente, do Plano Diretor e dos Termos de Compromisso, permitiu compreender a proposta do instrumento urbanístico, bem como a sua aplicação ao longo de dez anos. Através da tabela de dados fornecida pela prefeitura, via Lei de Acesso à Informação, procedeu-se a classificação de usos dos empreendimentos e das obrigações e contrapartidas. Por fim, através de software de geoprocessamento, os projetos foram espacializados sobre diferentes mapas de Porto Alegre, como por exemplo, o mapa do modelo espacial de desenvolvimento urbano, permitindo verificar a consonância dos projetos com o modelo de cidade proposto no Plano Diretor.

\section{Projetos Especiais e Planejamento flexível}

O Quadro 1 apresenta alguns dos P.E.2 que integram o levantamento elaborado nesta pesquisa:

${ }^{2}$ O NEPEEU está vinculado à Faculdade de Ciências Econômicas da Universidade Federal do Rio Grande do Sul e é coordenado pelo Professor Dr. Fabian Scholze Domingues.

${ }^{3} \mathrm{O}$ Termo de Compromisso consiste em um negócio jurídico bilateral, firmado entre o Município e empreendedor privado, no qual são ajustadas obrigações urbanísticas e ambientais para o licenciamento urbano-ambiental do projeto. 
Quadro 1 - Exemplos de Projetos Especiais de 2o Grau em Porto Alegre (2010 - 2019).

\begin{tabular}{|c|c|c|c|c|}
\hline Empreendimento & Responsável & Endereço & Data do T.C. & Atividade \\
\hline Shopping Praia de Belas & $\begin{array}{c}\text { Shopping Praia de } \\
\text { Belas }\end{array}$ & $\begin{array}{c}\text { Av. Praia de Belas, } \\
1181\end{array}$ & $05 / 03 / 2010$ & Comercial + \\
\hline Icon Assis Brasil & Melnick Even Opala & Av. Assis Brasil, 4600 & $17 / 01 / 2013$ & Comercial + \\
\hline Villa Bella & Encorp Engenharia & R. Atílio Superti, 340 & $19 / 07 / 2013$ & Residencial \\
\hline $\begin{array}{c}\text { Quartier Cabral/ Zaffari } \\
\text { Cabral }\end{array}$ & Melnick Even/ Zaffari & R. Cabral, 600 & $02 / 05 / 2015$ & Misto \\
\hline \begin{tabular}{c} 
Parque Porto La Palma \\
\hline MRV Engenharia e \\
Participações S/A
\end{tabular} & $\begin{array}{c}\text { Travessa Esporte Clube } \\
\text { Cruzeiro, 200 }\end{array}$ & $04 / 08 / 2016$ & Residencial \\
\hline Hipermercado Big & WMS e Walmart & Av. Sertório, 6600 & $26 / 03 / 2018$ & Comercial \\
\hline
\end{tabular}

Fonte: PMPA via Lei de Acesso à Informação (2019).

Como pode-se observar, há empreendimentos de uso residencial, comercial, misto, entre outros. Quanto aos empreendedores, encontram-se desde construtoras locais, com atuação mais restrita à região metropolitana (a exemplo da Encorp Engenharia), até construtoras de atuação em escala nacional (MRV Engenharia) e grupos multinacionais (por exemplo Walmart).

Tais projetos, além de permitirem identificar as principais tendências para os grandes empreendimentos imobiliários realizados em Porto Alegre nos últimos dez anos, também possibilitam avaliar as estratégias previstas no Plano Diretor, em especial, a Estratégia de Produção de Cidade. Esta estratégia contempla o Programa de Projetos Especiais "que busca promover intervenções que, pela multiplicidade de agentes envolvidos no seu processo de produção ou por suas especificidades ou localização, necessitam critérios especiais e passam por acordos programáticos estabelecidos com o Poder Público (...)" (PORTO ALEGRE, 2010, p.36, grifo nosso).

Neste sentido, o objeto de estudo apresenta-se como fenômeno transescalar, que:

apesar de manifestar-se em escala local, só pode ser explicado quando se amplia o olhar para a escala internacional. Os projetos especiais são entendidos aqui como um 
instrumento do planejamento urbano flexível - este concebido como um conjunto de práticas de planejamento que ganha força a partir dos anos 1970 nos países de capitalismo central e na sequência disseminado para outros países, entre eles, o Brasil. 0 planejamento flexível só pode ser entendido à luz de fenômenos globais como neoliberalismo, acumulação flexível, globalização e financeirização. Logo, para entenderse o planejamento urbano praticado no Brasil hoje, mais especificamente em Porto Alegre, é necessário compreender estes fenômenos de escala global e como os mesmos repercutem no espaço urbano por meio das práticas de planejamento e gestão do espaço (FAGUNDES, 2019, n.p., p. 27).

Assim, os Projetos Especiais são melhor compreendidos quando vistos como uma das manifestações de um modelo de planejamento urbano flexível, que guarda forte relação com o planejamento estratégico (VAINER, 2016; SOUZA, 2015). Este modelo caracteriza-se pela competitividade, flexibilidade e orientação para o mercado. Adota a racionalidade da supremacia do projeto urbano em detrimento do planejamento urbano de longo prazo, e apoia-se na figura do contrato para viabilizar alterações no zoneamento urbano em troca da prestação de obrigações que concorrem para o financiamento da infraestrutura de interesse geral. Neste contexto observa-se a redução da presença do Estado como produtor e regulador do espaço urbano e a transferência sistemática destas funções para a iniciativa privada, transferindo o planejamento da cidade para a escala do lote privado.

Inseridos neste cenário, os P.E.2 são operacionalizados através de um Termo de Compromisso (TC), consistente em um negócio jurídico bilateral, firmado entre o Município e os empreendedores, no contexto do licenciamento urbano-ambiental. Tais termos demonstram a incorporação de um modelo de planejamento e gestão urbanas aberto à negociação, seguindo uma tendência adotada em países europeus para flexibilizar o planejamento e viabilizar projetos urbanos de grande porte (EUROPEAN COMMISSION, 1997; COMPASS, 2019). Na concertação, são inseridas obrigações (execução de infraestrutura, construção de equipamentos públicos) a cargo dos empreendedores, genericamente tratadas como "contrapartidas" ao direito de construir (VIZZOTTO, 2018), que são cumpridas ao longo dos anos, pois os projetos urbanos são complexos, envolvem grandes investimentos e são baseados na expectativa de atraírem novos negócios e usuários para as áreas nas quais são implementados (GIELEN, 2010). 
No caso de Porto Alegre, os P.E. foram inicialmente concebidos para comportar as exceções ao modelo espacial de ordenamento territorial do plano diretor. Porém, a pesquisa ora em curso revelou que, longe de se constituírem casos pontuais, os P.E.2 se tornaram regra para os grandes empreendimentos realizados na cidade, compondo uma verdadeira onda de choque dos empreendimentos imobiliários de grande porte em Porto Alegre, com forte incentivo ao remembramento de lotes. Embora este instrumento tenha sido inspirado no Estatuto da Cidade (documento de 2001 que regulamenta o capítulo "Política Urbana" na Constituição Federal de 1988) sua aplicação sui generis em Porto Alegre, porquanto desprovida de lei específica que disponha sobre as flexibilizações do regime urbanístico, permite recortar um interessante objeto de análise urbanística, espacial, jurídica e econômica, que identifica padrões dentro da exceção, isto é, os tipos de projetos, as áreas e os beneficiários são reconhecíveis a partir dos respectivos padrões de construção, uso, localização, público beneficiário, etc.

\section{O quadro normativo dos Projetos Especiais}

O Plano Diretor de Porto Alegre (LC 434/99) acolheu o modelo do Planejamento Estratégico baseado na ideia de flexibilização das normas urbanísticas, conforme se depreende do discurso inserido na Justificativa que acompanha o PDDUA. No texto, há referência expressa a discursos próprios deste modelo de planejamento (CASTELLS e BORJA, 1996; GÜELL, 2008), que passaram a ser adotados por cidades norte-americanas e europeias a partir dos anos 1980, como uma reação ao planejamento integrado, reputado tecnocrático e rígido (GIELEN \& TASAN-KOK, 2010; HEALEY et al, 2010) e como manifestação da racionalidade neoliberal (DARDOT; LAVAL, 2016).

Assumindo, portanto, um discurso competitivo e empreendedor, o PDDUA, aprovado em 1999, afirma que

para captar todas estas potencialidades, impõe-se mais do que nunca, a articulação entre o setor privado e o público, fazendo com que o primeiro aporte suas energias e criatividade sócio-econômica para a qualidade do conjunto e que o Estado reivindique e assuma sua capacidade de articulador e promotor, na sua responsabilidade pela tutela do bem estar coletivo. Uma cidade com este nível de concertação econômica e solidariedade 
social, estará em melhores condições de explorar todas as suas potencialidades, promovendo seu autofinanciamento e, por consequência sua sustentabilidade como um todo (PORTO ALEGRE, 2010, p. 03).

Uma das estratégias adotadas no 2o PDDUA foi a utilização de Projetos Especiais, justificados pelo arquiteto e consultor internacional Jorge $\mathrm{H}$. Pérez como uma forma de enfatizar o projeto urbano no contexto do planejamento. Para Pérez, que foi contratado como consultor do processo de revisão do plano, o Projeto Especial teria como objetivo valorizar áreas urbanas dotadas de "consideráveis dimensões, localizadas em sítios com valores naturais e/ou culturais" (PÉREZ, 1998), devendo ser analisado conforme suas peculiaridades e a partir de consensos entre o Município e as partes interessadas.

Em 2010, por meio da LC 646, o PDDUA foi revisado, mantendo-se o instrumento dos Projetos Especiais de Impacto Urbano ${ }^{4}$, agora formulado para abarcar propostas que permitam flexibilização de limites de altura, dentre outros padrões. 0 art. 58 do PDDUA estipula que, “(...), mediante Projeto Especial de Impacto Urbano, poderão ser alterados os padrões previstos para recuos de ajardinamento, regime de atividades, regime volumétrico, parcelamento do solo, garagens e estacionamentos". Apenas a alteração de padrões previstos para o Índice de Aproveitamento e Quota Ideal mínima por terreno dependem de lei específica (art. 58, §1o.).

$\mathrm{O}$ art. 59 estabelece que mediante a análise das características diferenciadas, complexidade e abrangência, os P.E. se classificam em: I - Projeto Especial de Impacto Urbano de 10 Grau; II - Projeto Especial de Impacto Urbano de 2o Grau; e III - Projeto Especial de Impacto Urbano de 3ํ Grau (Operação Urbana Consorciada). Lembrando que se trata de uma escala crescente de geração de impactos.

Algumas atividades classificadas como Impacto Urbano de 1으 grau são: Centro comercial com área adensável entre $5.000 \mathrm{~m}^{2}$ e $10.000 \mathrm{~m}^{2}$; Centro de eventos com área adensável entre $750 \mathrm{~m}^{2}$ e $5.000 \mathrm{~m}^{2}$; Equipamento administrativo ou de segurança pública; Garagem

\footnotetext{
${ }^{4} \mathrm{O}$ art. 54-A do PDDUA o define como "a proposta de empreendimento ou atividade listado no Anexo 11 desta LC, devendo observar, no que couber, os seguintes objetivos: I - viabilização das diretrizes e estratégias do PDDUA; II promoção do desenvolvimento urbano a partir do interesse público, de forma concertada com o interesse privado; III - detalhamento deste PDDUA com base em estudos específicos; IV - solução dos impactos urbano-ambientais decorrentes da proposta; V - qualificação da paisagem urbana, reconhecendo suas diversidades e suas configurações socioespaciais; e, VI - compatibilização das diversas políticas setoriais e do plano regulador com as diferentes escalas espaciais - terreno, quarteirão ou setor urbano".
} 
comercial com 100 a 200 vagas; Hospital; Supermercado com área adensável entre $500 \mathrm{~m}^{2}$ e $10.000 m^{2}$. Alguns empreendimentos que recebem a mesma classificação são: Edificação de médio porte ${ }^{5}$, isoladamente ou em conjunto; Edificação e parcelamento do solo em terreno que apresente bem tombado ou inventariado; e Loteamento com área entre 2,25ha e 30ha, em Área de Ocupação Intensiva.

Algumas atividades classificadas como Impacto Urbano de 2 o grau, por sua vez, são: Aeroporto; Cemitério; Centro comercial com área adensável superior a $10.000 \mathrm{~m}^{2}$; Estádios e Arenas esportivas; Garagem comercial com mais de 200 vagas; e Supermercado com área adensável superior a $10.000 \mathrm{~m}^{2}$. Alguns empreendimentos com impacto urbano de $2 \stackrel{\circ}{\text { grau }}$ são: edificações com taxa de ocupação superior a $300 \mathrm{~m}^{2}$ em Área de Proteção do ambiente natural com proposta de ocupação sobre zona de conservação; Edificação de grande porte em Área Especial sem regime urbanístico definido; e Loteamento em Área de Ocupação Rarefeita.

Ressalta-se que os Projetos Especiais de 1으 grau, por causarem menos impactos, não geram termos de compromisso e por isso identificá-los torna-se tarefa bastante difícil. Já os Projetos Especiais de 3o grau, também conhecidos no Estatuto da Cidade como Operações Urbanas Consorciadas (OUCS) ainda não foram registrados em Porto Alegre..

\section{Os Projetos Especiais em análise comparada}

Observa-se que o tratamento jurídico concedido ao P.E., a partir da normativa propiciada pelo Plano Diretor, confere-Ihe grande flexibilidade, consoante a lógica do "caso a caso". Tal circunstância permite uma aproximação deste instituto com práticas que têm sido adotadas em alguns países europeus, como Inglaterra, Holanda e Espanha, que se valem de acordos urbanísticos prévios às emissões de autorizações para construir, no qual estabelecem obrigações urbanísticas para a finalidade de mitigar e compensar impactos urbanísticos e ambientais negativos, recuperar a valorização imobiliária do empreendimento e evitar custos com urbanização para o Poder Público (RIVOLIN, 2008; VAN DER VEEN, 2009; GIELEN

\footnotetext{
${ }^{5}$ A lei considera de pequeno porte o empreendimento ou atividade não residencial com limites inferiores a $10.000 \mathrm{~m}^{2}$. É considerada de médio porte a edificação não residencial com área adensável entre $10.000 \mathrm{~m}^{2} \mathrm{e}$ $30.000 \mathrm{~m}^{2}$ ou com guarda de veículos entre 200 e 400 vagas. Já a edificação de grande porte é aquela com área adensável superior a $30.000 \mathrm{~m}^{2}$ ou com mais de 400 vagas de estacionamento.
} 
\& TASAN-KOK, 2010; GIELEN, 2009; GIELEN \& LENFERINK, 2018, NADIN \& STEAD, 2008; CARDOSO, 2008; STEAD, DE VRIES \& TASAN-KOK, 2017; COMPASS, 2019). Nessa perspectiva, observa-se que os P.E. se inserem em uma lógica globalizada de produção da cidade, em que os atores econômicos negociam com o setor público a implantação de seus empreendimentos, em detrimento das regras gerais estabelecidas no plano de ordenamento municipal, sob a promessa de criar espaços inovadores e atrativos para novos investimentos (VAINER, 2002; LEAL, 2017).

No entanto, há distinções que merecem relevo, a partir de uma abordagem jurídica comparada. Nos países que adotam a possibilidade de acordos no âmbito da aprovação de projetos urbanos, como os países do Reino Unido, Portugal e Espanha, há lei federal que disciplina o planejamento urbano e que explicita as hipóteses de incidência de encargos urbanísticos, de medidas de natureza mitigatória e compensatória de impactos negativos, diferenciando-as das obrigações relacionadas ao financiamento da cidade (OLIVEIRA, 2011; FERNÁNDEZ, 2019). Colaciona-se como principal exemplo o britânico, que trata das obrigações mitigatórias na Town and Country Planning Act 1990, Section 106, como "planning obligations" e ainda prevê a figura de uma contribuição pelo direito de construir, prevista na Community Infrastructure Levy ${ }^{6}$, destinada ao custeio da infraestrutura pública (COMPASS, 2019; CULLINGWORTH, 2015; CROOK, HENNEBERRY \& WHITEHEAD, 2016). Nesse modelo, o contrato (development agreement) é assinado antes da aprovação do projeto urbano.

Além disso, nos países europeus, por força da Diretiva 2001/42 do Parlamento Europeu e do Conselho, realizam-se avaliações ambientais estratégicas de planos urbanos ${ }^{7}$, sem prejuízo da elaboração de Estudo de Impacto Ambiental para avaliação de projetos, de tal forma que a definição de obrigações de natureza mitigatória e compensatória de impactos encontra sólida motivação técnica e é coerente com o ordenamento global do território. Este conjunto normativo multiescalar, também submetido às normas comunitárias e ao princípio

\footnotetext{
${ }^{6}$ https://www.gov.uk/guidance/community-infrastructure-levy\#introduction, acesso em 10 de dezembro de 2019.

A

respeito,

ver

https://www.unece.org/fileadmin/DAM/env/eia/documents/EC SEA Guidance/ec 030923 sea guidance pt. pdf, acesso em 10 de dezembro de 2019.
} 
da integração, favorece a redução da discricionariedade administrativa das autoridades locais encarregadas de aprovar os projetos urbanos.

No Brasil, inexiste legislação federal que discipline a concertação urbanística para viabilização de projetos urbanos, muito embora a possibilidade decorra do art. 5o, §6o., da Lei 7347/85, combinado com o art. 79-A, da Lei 9.605/98, e transpareça no Estatuto da Cidade (Lei Federal 10.257/2001). Tampouco há parâmetros específicos para a concertação, com a explicitação das obrigações urbanísticas cabíveis, salvo o disposto no recente art. 3o., inciso XI, da Lei Federal 13.874/2019, que trata das medidas ou prestações compensatórias ou mitigatórias "abusivas", assim entendidas aquelas que não guardam relação causal direta com os impactos negativos do projeto urbano.

No caso de Porto Alegre, não há exigência de Estudo de Impacto de Vizinhança para a análise dos P.E., apesar de sua previsão no PDDUA e na LC 695/2012, pela falta de regulamentação legal. Por esse motivo, as obrigações mitigadoras e compensatórias são exigidas pelas secretarias municipais com base em estudos diversos (estudo de mobilidade, laudos de cobertura vegetal, estudos de drenagem, etc.), e não se exige contrapartida por valorização imobiliária, aspecto este que precisaria ser avaliado em EIV ${ }^{8}$. As contrapartidas, na legislação municipal, são disciplinadas apenas na LC 850/2019, que trata da outorga onerosa do direito de construir (solo criado), aspecto este que, em uma análise formal dos termos de compromisso disponibilizados pela Procuradoria Geral do Município, não é explicitado, embora não se descarte a possibilidade de que haja a aquisição de solo nos P.E. em que ocorra o acréscimo de altura.

\section{Descrição e análise socioespacial}

Inicialmente, foi apurado o total de P.E.2 aprovados no período 2010-2019 e observado sua distribuição ao longo dos anos, considerando-se para tanto, o ano de assinatura do T.C. entre empreendedor e Procuradoria Geral do Município. Em alguns casos, que merecem uma análise à parte, além do T.C. foram assinados Termos Aditivos repactuando os

\footnotetext{
${ }^{8}$ A possibilidade consta do art. 7o., V, da LC 695/12, que não foi regulamentada.
} 
compromissos entre as partes envolvidas. No Gráfico 1, apresenta-se a distribuição dos P.E. no período estudado, considerando-se a data de assinatura do primeiro T.C.:

Gráfico 1 - Número de Projetos Especiais por ano (1997 - 2019).

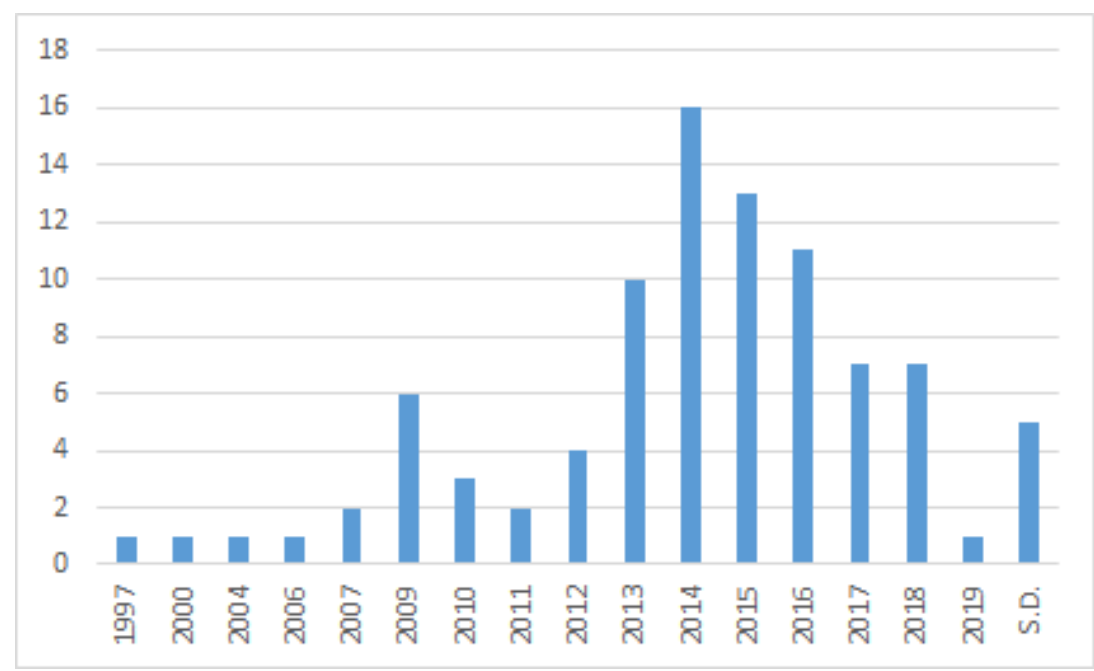

Fonte: PMPA via Lei de Acesso à Informação (2019).

Como pode-se observar no Gráfico 1, os anos com maior número de Projetos Especiais de $2^{\circ}$ grau foram 2013 (10), 2014 (16), 2015 (13) e 2016 (11). Cinco P.E.2 não tiveram a data de assinatura registrada, e não foi possível encontrar a informação. Entre 2010 e 2019, foram registrados 74 P.E.2, enquanto 12 foram anteriores ao recorte temporal da pesquisa, incluídos na lista em função das datas de seus Termos Aditivos, assinados após 2010.

Partindo da constatação de que o PDDUA traz uma proposta de desenvolvimento, qualificação e expansão urbana para o município, cujas diretrizes encontram-se espacializadas na Parte I do plano; aliada ao fato de que os P.E. são um dos instrumentos que integram este plano; as características dos P.E.2 foram comparadas às diretrizes espaciais do PDDUA, de forma a verificar se os projetos aprovados no período estudado vem respeitando ou descaracterizando o modelo espacial.

Na Parte $l^{9}$ do PDDUA, são apresentadas uma série de divisões territoriais para Porto Alegre. Inserido no título II Das Estratégias, está o capítulo VI Da Produção da Cidade, composto por

\footnotetext{
${ }^{9}$ Dividida entre os títulos I - Dos Princípios, II - Das Estratégias e III - Do Modelo Espacial.
} 
cinco diretrizes espaciais básicas, dentre as quais, a já mencionada diretriz I, Estratégia de Produção da Cidade: Programa de Projetos Especiais:

Art. 23. Compõem a Estratégia de Produção da Cidade:

1 - Programa de Projetos Especiais, que busca promover intervenções que, pela multiplicidade de agentes envolvidos no seu processo de produção ou por suas especificidades ou localização, necessitam critérios especiais e passam por acordos programáticos estabelecidos com o Poder Público, tendo como referência os padrões definidos no Plano Regulador (PORTO ALEGRE, 2010, p.36).

No mapa que apresenta o programa no Plano Diretor, estão especificados agentes (PMPA, Setor Privado, Setor Hoteleiro, Setor Informal, União, Exército etc.) e perfis de empreendimento para cada área demarcada. O texto, no entanto, não detalha se tais áreas são delimitações rígidas a serem seguidas ou áreas meramente recomendadas para tais empreendimentos. Tampouco especifica se diz respeito somente a P.E. de Realização Necessária (de iniciativa do Poder Público) ou também a P.E. de Realização Voluntária (de iniciativa de agentes privados) ${ }^{10}$. Não obstante, foram sobrepostos os P.E.2 levantados pela pesquisa ao Mapa do Programa de Projetos Especiais do Plano Diretor, chegando-se ao mapa exposto na Figura 1.

10 Através de conversas com participantes da elaboração do plano, chegou-se ao entendimento de que o mapa seria direcionado a P.E. de Realização Necessária, ou seja, de iniciativa do Poder Público. 


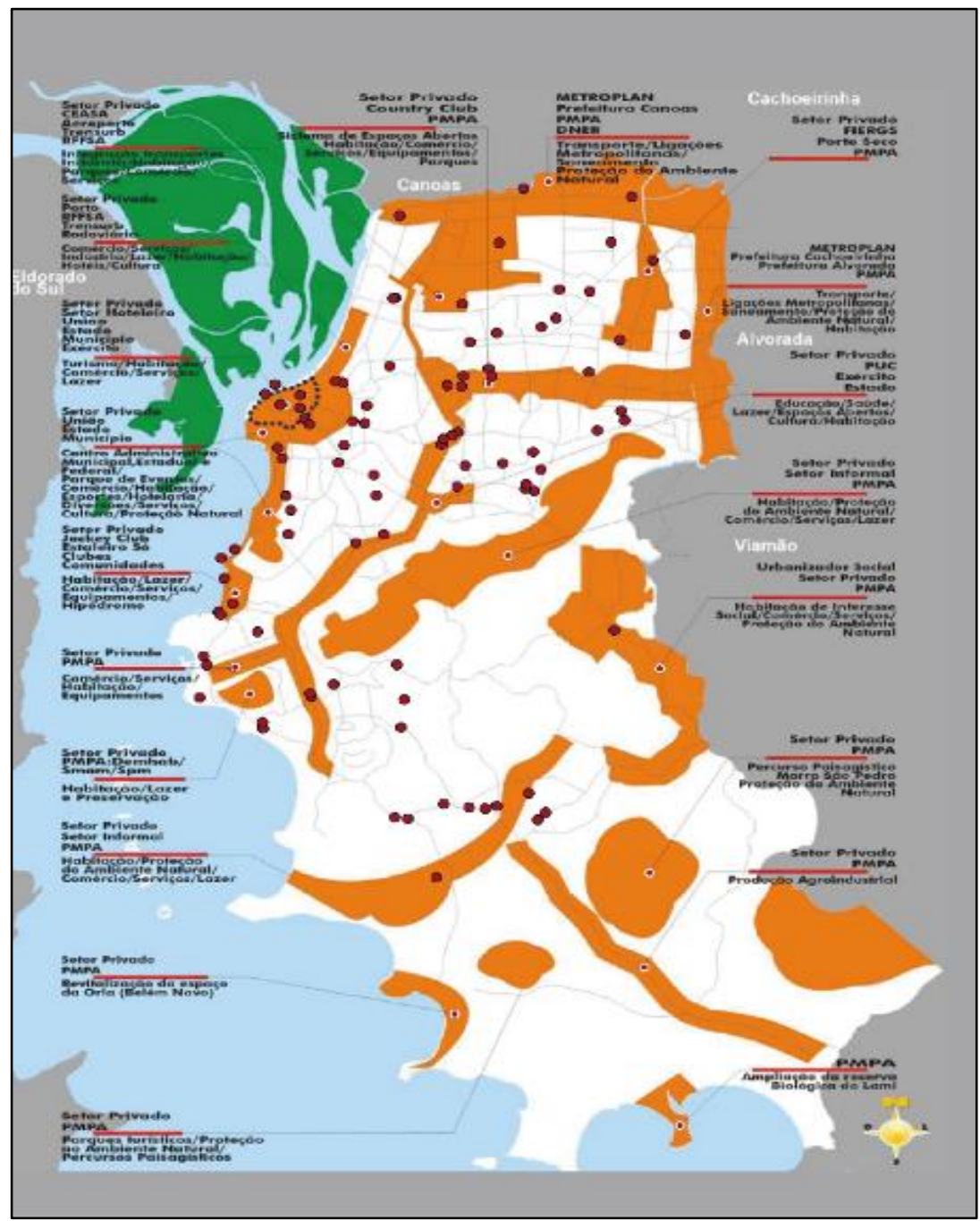

Figura 1 - Estratégia de Produção da Cidade - Programa de Projetos Especiais (PDDUA) e Projetos Especiais de 20 grau (2010 - 2019).

Fonte: PORTO ALEGRE (2010) e NEPEU (2019).

Como é possível observar na Figura 1, a sobreposição dos P.E.2 ao mapa do Programa de Projetos Especiais demonstra que as áreas sinalizadas pelo plano não têm servido de orientação para a aprovação dos P.E. tabulados nesta pesquisa. 


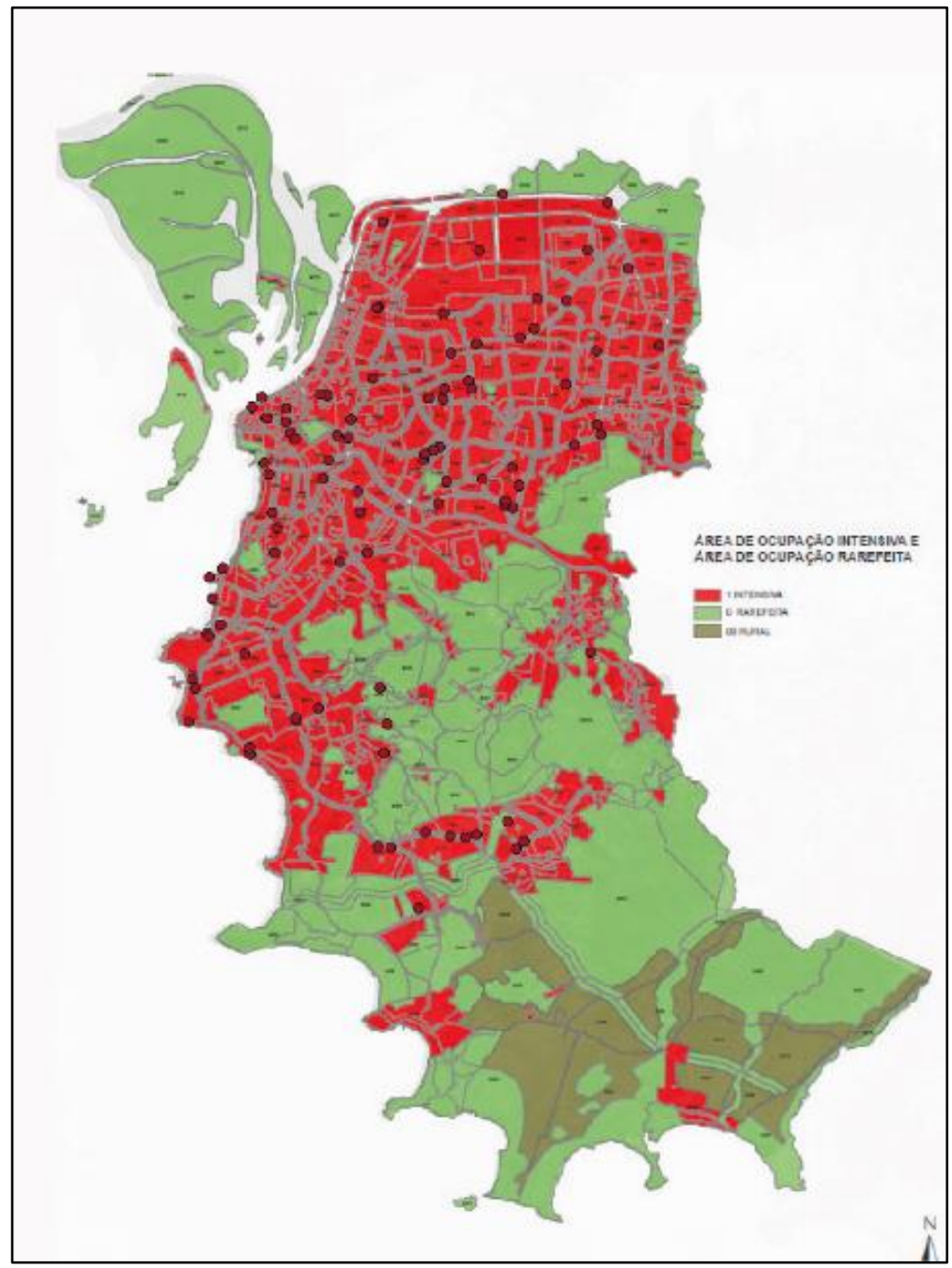

Figura 2 - Estratégia de Produção da Cidade - Área de Ocupação Intensiva e Rarefeita X UEU e Projetos Especiais de 20 grau (2010 - 2019).

Fonte: PORTO ALEGRE (2010) e NEPEU (2019).

Ainda dentro dos conceitos da Parte I do PDDUA, foram avaliadas outras duas divisões territoriais, contidas no título III Do Modelo Espacial ${ }^{11}$. Na Figura 2 é possível visualizar o território de Porto Alegre dividido em Área de Ocupação Intensiva (AOI) e Área de Ocupação Rarefeita $(A O R)^{12}$. Ao efetuar a sobreposição com os P.E.2, verificou-se que a quase totalidade dos projetos se localiza dentro da Área de Ocupação Intensiva, caracterizada

\footnotetext{
${ }^{11}$ O Modelo Espacial é definido pelo PDDUA como o conjunto das diretrizes de desenvolvimento urbano expresso através de representações espaciais consubstanciadas nas Estratégias.

${ }^{12}$ Este mapa está disponível no site da prefeitura, "Guia de Consulta: Regime Urbanístico" e foi aqui utilizado por se tratar de uma versão mais atualizada (versão Janeiro/2019) do que aquela constante no PDDUA. Disponível em: <http://lproweb.procempa.com.br/pmpa/prefpoa/spm/usu doc/guia pddua.pdf> . Acesso em: nov. 2019.
} 
como prioritária para fins de urbanização, onde se busca potencializar a estruturação urbana preexistente e otimizar o seu uso. Tal perfil sugere que, no que concerne a este zoneamento territorial, a localização dos P.E.2 está em conformidade com os objetivos gerais traçados pelo PDDUA. É interessante notar, porém, que no bairro Campo Novo a disposição espacial de três P.E.2, no limiar entre AOI e AOR, sugere uma tendência de avanço da urbanização intensiva em direção à área de ocupação rarefeita.

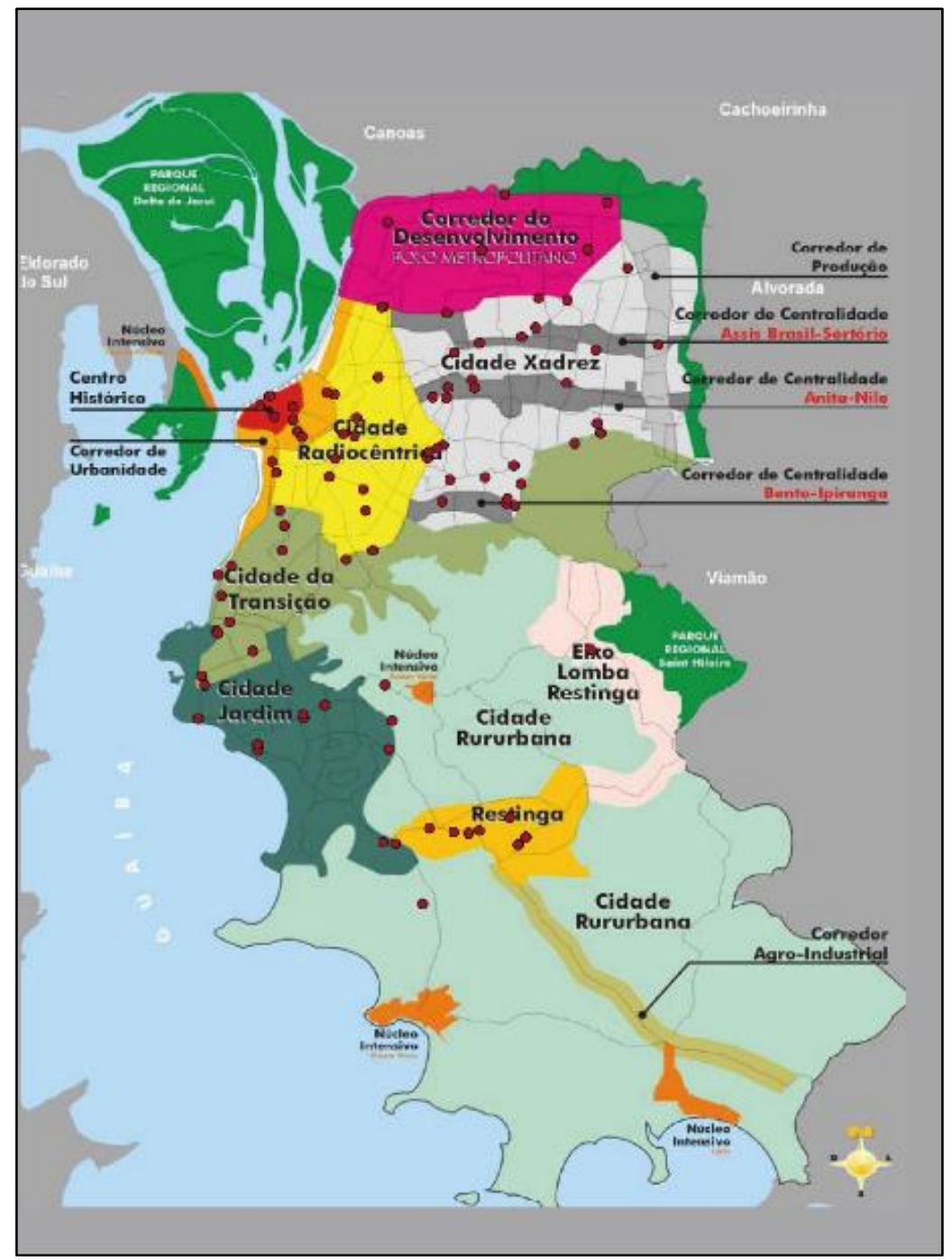

Figura 3 - Macrozonas e Projetos Especiais de 2o grau (2010 - 2019).

Fonte: PORTO ALEGRE (2010) e NEPEU (2019). 


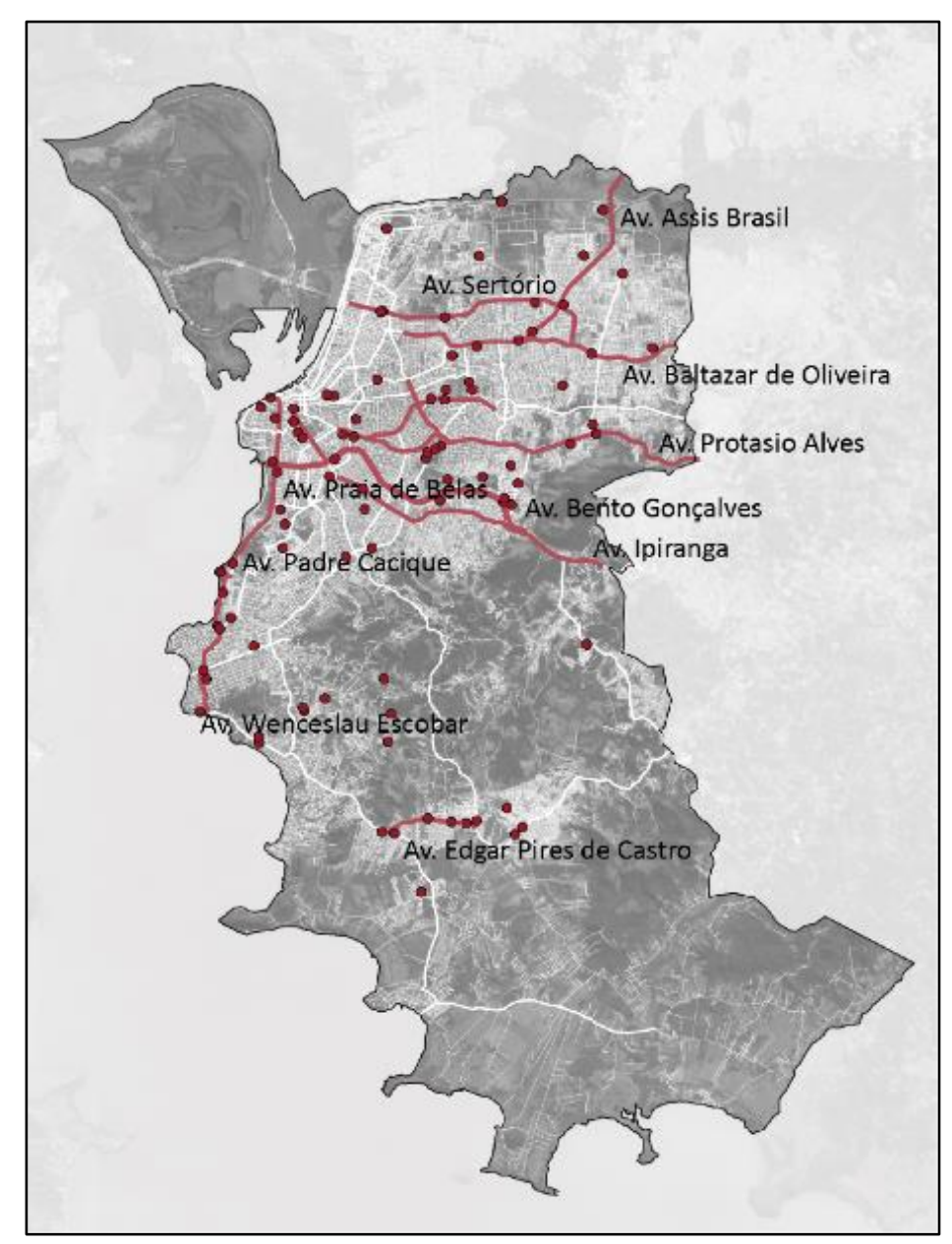

Figura 4 - Eixos arteriais e Projetos Especiais de 2ㅇ grau (2010 - 2019).

Fonte: NEPEU (2019).

A terceira divisão territorial analisada apresenta as Macrozonas e os Elementos Estruturadores do Modelo Espacial da cidade. Como pode-se observar Figura 3, cada macrozona reúne um conjunto de unidades menores, denominadas Unidades de Estruturação Urbana (UEUs), concebidas como módulos estruturadores do Modelo Espacial definidos pela malha viária básica. O posicionamento dos P.E.2 sobre as Macrozonas (Figura 3), demonstra uma distribuição desigual de projetos entre as nove macrozonas da cidade, com clara concentração de projetos nas macrozonas 1 - Cidade Radiocêntrica (26\%) e 3 Cidade Xadrez (26\%), regiões consolidadas do município. Ademais, a imagem sugere que os Elementos Estruturadores do Modelo Espacial, tais como Corredores de Centralidade, que visam a estruturar uma rede de pólos comerciais multifuncionais; Corredor de Produção, onde é amplamente estimulada a atividade produtiva passível de convivência com a atividade residencial; e Corredor Agroindustrial, com potencial para a localização de 
indústrias não-poluentes de produtos vinculados à produção primária; não tem tido papel muito relevante na definição da localização dos projetos aprovados através do instrumento.

Examinando a localização dos P.E.2 em relação às vias de circulação, é possível verificar que sua distribuição espacial no município se concentra essencialmente junto aos eixos arteriais da cidade. Como demonstrado na Figura 4, a sobreposição permite atestar com relativa segurança que enquanto parte dos projetos se encontram em zonas consolidadas e economicamente valorizadas da cidade, outra parte se encontra justamente na área de expansão da mancha urbana, chamando atenção o grande número de P.E.2 na zona sul de Porto Alegre, mais especificamente na avenida Edgar Pires de Castro, que apresenta uma grande quantidade de projetos especiais, indicando um processo de urbanização via aplicação de P.E.2 (JULIO, 2018).

Na Figura 5, confrontou-se a distribuição espacial dos P.E.2 com a distribuição da renda (marcador renda média de responsável por domicílio, conforme Censo 2010). Percebeu-se que a maior concentração de P.E.2 ocorre nos bairros onde a renda média é mais alta, o que corrobora a hipótese de que tais projetos reforçam a segregação socioespacial na cidade, à medida que investem em áreas já densificadas, dotadas de boa infraestrutura urbana e onde o preço da terra tradicionalmente já é mais caro, elevando ainda mais estes valores. 


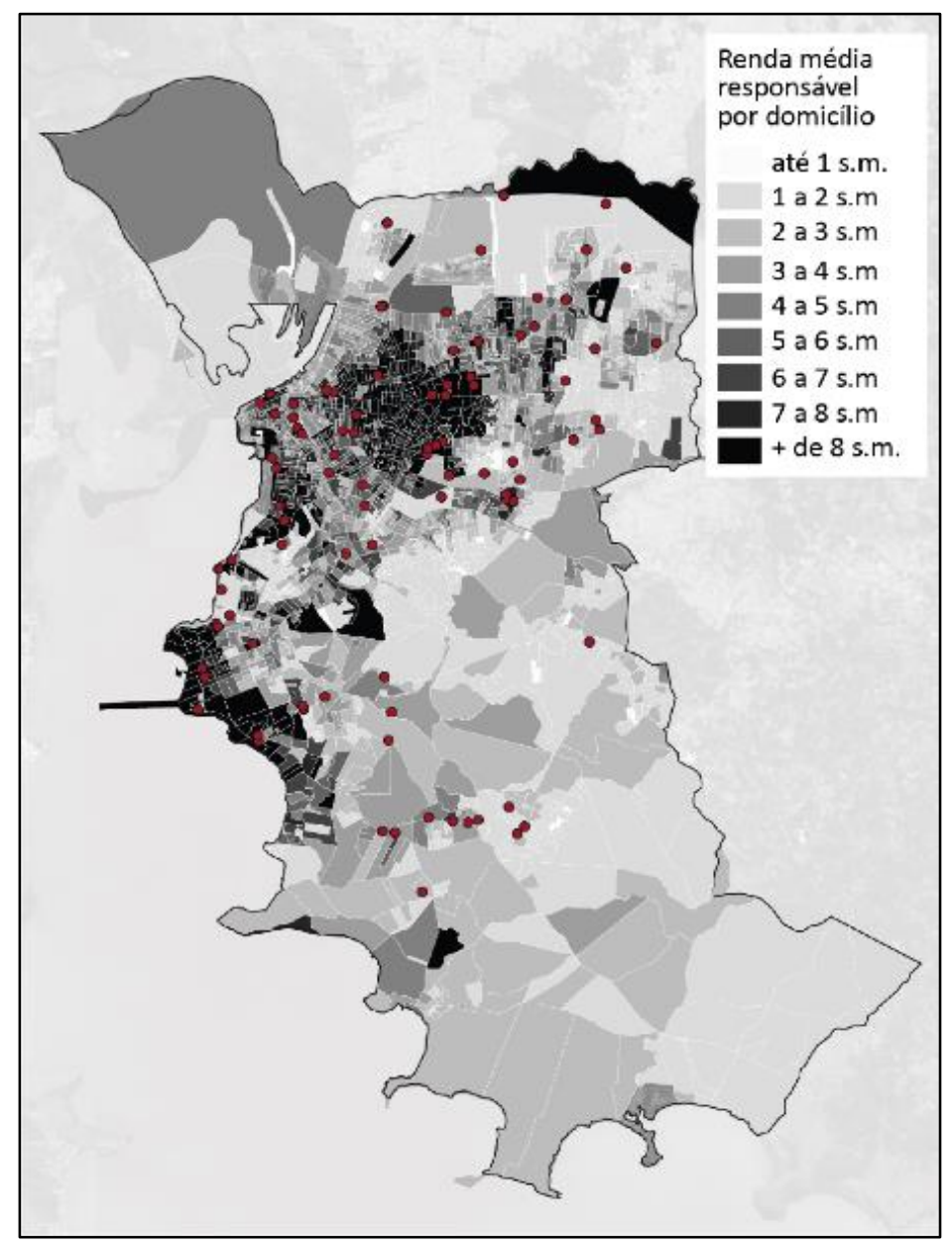

Figura 5 - Renda média de responsável por domicílio por setor censitário em Porto Alegre (2010) e Projetos Especiais de 2ㅇ grau (2010 - 2019).

Fonte: IBGE (2010) e NEPEU (2019).

Ressalta-se, entretanto, que alguns projetos localizados em outras áreas da cidade, como na zona sul, a exemplo da Av. Edgar Pires de Castro, apresentam outro perfil de empreendimento, tendo as classes populares como público-alvo. Estes empreendimentos se caracterizam por valores finais mais baixos, em áreas de pouca infraestrutura urbana e afastadas das áreas centrais (muitas vezes com difícil acesso), reforçando desta forma a segregação socioespacial de uma parcela da população de baixa renda que busca acessar moradia via mercado formal, mas permanece com as mesmas condições de acesso restrito à infraestrutura e serviços urbanos de qualidade. 


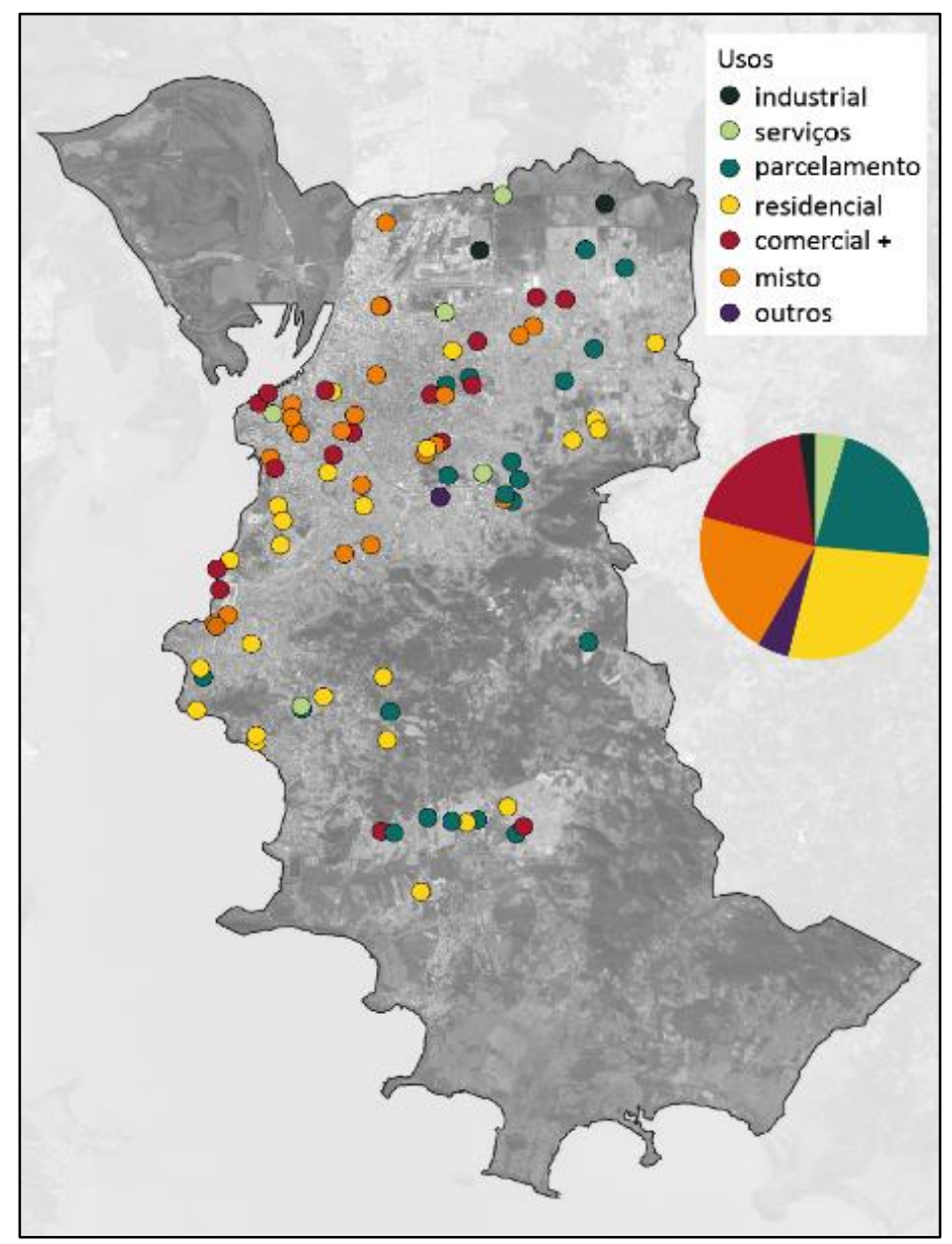

Figura 6 - Classificação de uso dos Projetos Especiais de 2o grau (2010 - 2019).

Fonte: NEPEU (2019).

Em relação aos tipos de uso dos empreendimentos, os P.E.2 foram agrupados em sete macrocategorias. Como pode-se observar na Figura 6, a maior parte dos projetos aprovados é de uso residencial (26\%); seguido por projetos de parcelamento do solo (22\%) e projetos de uso misto (21\%), sendo estes caracterizados por uso residencial agregado a algum outro uso. Em quantidade menor, observou-se projetos de uso comercial $+(19 \%)^{13}$; uso comercial (9\%); serviços (5\%) e; uso industrial (2\%). Na categoria outros (5\%) foram reunidos usos que tiveram baixa ocorrência nos dados tabulados, remetendo a usos de saúde, educação, esporte e parcelamento do solo + uso misto.

Em relação ao uso residencial, percebe-se um padrão de localização disperso, com empreendimentos localizados tanto em regiões já consolidadas e economicamente

\footnotetext{
${ }^{13}$ Nomenclatura adotada para projetos com uso comercial exclusivo ou agregado a usos de serviço, cultura ou educação.
} 
valorizadas nas zonas central, leste e sul da cidade, quanto em áreas periféricas, como os empreendimentos na Av. Edgar Pires de Castro, no bairro Campo Novo (zona sul) e na intersecção das Av. Manoel Elias e Av. Protásio Alves, na zona leste da cidade.

Os empreendimentos de uso misto, por sua vez, apresentam localizações, no geral, orientadas a partir do padrão de urbanização radiocêntrico que constitui a primeira macrozona da cidade, estando a maior parte deles situada na região circunscrita pela Avenida Terceira Perimetral. Tanto a categoria de uso misto quanto de uso comercial + estão presentes principalmente em eixos arteriais nas áreas consolidadas e economicamente valorizadas da cidade, assim como os P.E.2 de uso comercial e de serviços.

Os empreendimentos de parcelamento do solo, por outro lado, têm clara concentração nas áreas periféricas da mancha urbana, num padrão de localização coerente com sua natureza, que requer amplas áreas ainda não edificadas. É interessante observar que a localização destes empreendimentos acusa tendências gerais de provável avanço da fronteira imobiliária. Aponta, também, algumas parcelas da cidade que parecem estar sendo urbanizadas através do instrumento, como o trecho da Av. Edgar Pires de Castro e a intersecção entre Av. Ipiranga e Av. Antônio de Carvalho, onde há concentração e proximidade entre tais empreendimentos. Os demais usos identificados, em função da pequena quantidade de ocorrências, não geraram padrões de localização ${ }^{14}$.

Tais dados, em uma análise preliminar, corroboram a hipótese de que o instrumento vem sendo utilizado, principalmente, para a construção de grandes empreendimentos residenciais, em especial para a construção de condomínios de grande porte. Partindo das premissas de que (1) projetos residenciais compõem grande parte das edificações urbanas; (2) tais projetos estão, em sua ampla maioria, localizados em áreas que dispõem de regimes urbanísticos próprios; e (3) o instrumento de Projetos Especiais consiste em um mecanismo para a flexibilização de regimes urbanísticos na aprovação de projetos de caráter excepcional; pode-se afirmar com relativa segurança que a aprovação de projetos residenciais via instrumento de P.E.2, em número tão expressivo, denota a consolidação do planejamento flexível em Porto Alegre, ao privilegiar a negociação em detrimento da regra majoritária.

\footnotetext{
${ }^{14}$ Para mais detalhes sobre padrões espaciais gerados por P.E.2 em Porto Alegre, ver AGUIRRE (2019).
} 


\section{Padrões urbanísticos das obrigações e contrapartidas}

A partir do estudo das 'Obrigações' (informação obtida pela Lei de Acesso à Informação) foi possível identificar os principais padrões das obrigações estipuladas pelo Município aos empreendedores para viabilizar os P.E.2. As obrigações, por vezes, aparecem nos termos de compromisso como "contrapartidas" 15 , o que dificulta a investigação a respeito da função que a obrigação pactuada no Termo de Compromisso desempenha (mitigar/compensar impactos ou de recuperação de mais valias fundiárias).

A análise dos gráficos 2, 3 e 4 indica que a maior parte das obrigações está concentrada em obras viárias e de infraestrutura, necessárias para viabilizar o próprio empreendimento, porquanto mitigam os impactos negativos sobre essa infraestrutura.

Ao todo, os P.E. geraram 1.119 obrigações, sendo que destas, 732 foram qualificadas nos termos de compromisso como contrapartidas. As 387 obrigações que não se caracterizam como 'contrapartidas' ou 'substituições' ${ }^{16}$ são formadas basicamente por exigências por parte da PMPA para que o empreendedor siga uma determinada Lei ou ato normativo. No gráfico 3, é possível verificar as categorias de 'Obrigações', bem como os seus percentuais.

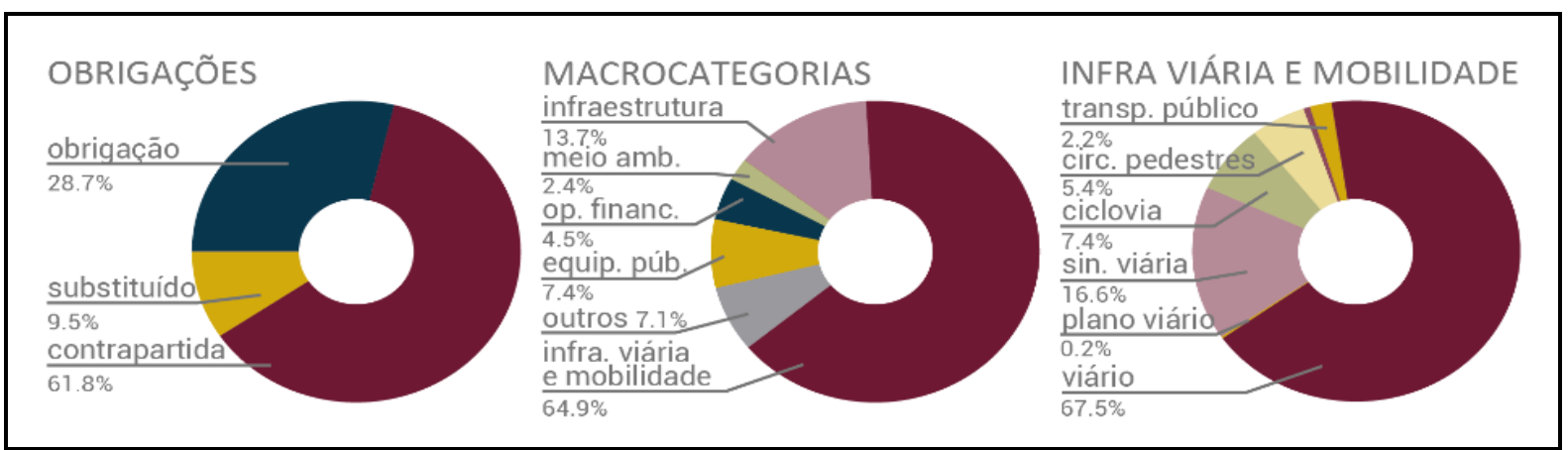

Gráfico 2, 3 e 4 - Padrões das obrigações dos Projetos Especiais de 2ํ grau.

Fonte: PMPA via Lei de Acesso à Informação (2019).

\footnotetext{
${ }^{15}$ A Prefeitura de Porto Alegre utiliza a expressão "contrapartida" para se referir às obrigações de natureza compensatória e mitigadora de impactos ambientais e urbanísticos, muito embora o Estatuto da Cidade empregue este termo ao se referir à outorga onerosa do direito de construir e à operação urbana consorciada. Estes instrumentos previstos no PDDUA versam sobre a possibilidade de flexibilização do regime geral previsto no plano.

${ }^{16}$ Nos dados fornecidos pela PMPA - via Lei de Acesso à Informação - constam os termos contratuais "substituídos" que formam uma categoria à parte, visto que antes de sua execução, foram substituídos por outras obrigações, sendo algumas delas contrapartidas e outras não. Por este motivo, os termos "substituídos" não foram posteriormente categorizados nem considerados um objeto relevante para esta pesquisa.
} 
Para obter uma visão de conjunto das obrigações pactuadas, elas foram divididas em seis macrocategorias: 1) Infraestrutura viária e mobilidade (abertura de vias, ciclovias etc.), 2) Infraestrutura (iluminação pública, saneamento etc.), 3) Equipamentos públicos (escolas, postos de saúde etc.), 4) Outros (patrimônio histórico, segurança pública etc.), 5) Operação financeira (doações, permutas etc.) e 6) Meio ambiente (arborização, medidas de preservação etc.). A distribuição percentual dessas categorias pode ser observada no gráfico 3, 'macrocategorias'.

Como a categoria 'Infraestrutura viária e mobilidade' corresponde a $65 \%$ do total de obrigações acordadas, considerou-se relevante dividir essa categoria em seis subcategorias. São elas: a) Abertura e manutenção de vias; b) Sinalização viária; c) Ciclovias; d) Obras para circulação de pedestres; e) Transporte público; e, f) Plano viário. Como é possível depreender do gráfico 4 'infraestrutura viária e mobilidade', a abertura e manutenção de vias é responsável por $67,5 \%$ do total da categoria 'Infraestrutura viária e mobilidade'. A expressividade da categoria 'Infraestrutura viária e mobilidade' evidencia que os P.E.2 são polos geradores de tráfego, além de demonstrar um reforço da lógica do urbanismo "carrocêntrico", isto é, baseado no transporte individual de passageiros.

As categorias de Infraestrutura e de Equipamentos Públicos também foram divididas em seis e cinco subcategorias, respectivamente, e foram analisadas em estudo mais detalhado em UTZIG (2019). No caso da Infraestrutura, os aportes mais significativos correspondem às obras de Pluvial e/ou drenagem, representando $42 \%$ da categoria. Já no caso dos Equipamentos Públicos, a maior parte dos aportes foram destinados a obras em praças públicas. Contudo, o estudo mais detalhado de JULIO (2017) identificou a criação de praças via este instrumento na Av. Edgar Pires de Castro sem que medidas de urbanização e colocação de mobiliário público tenham sido realizadas. Neste caso a 'praça' existe apenas como um campo gramado e vazio, contribuindo pouco ou nada para o lazer dos moradores do bairro e das vizinhanças.

A partir do percentual de obrigações urbanísticas mobilizadas para abertura e manutenção de vias juntamente com outras presentes nas demais categorias, é possível reforçar a hipótese de que, em Porto Alegre, são estipuladas preponderantemente medidas mitigadoras e compensatórias de impactos, em detrimento da oportunidade de recuperar a 
valorização imobiliária e de promover a distribuição dos ônus e benefícios da urbanização por meio de contrapartidas, com o sentido preconizado pelo Estatuto da Cidade.

\section{Considerações finais e Sugestões}

Neste artigo, buscou-se apresentar uma visão geral dos empreendimentos aprovados em Porto Alegre através do instrumento urbanístico Projetos Especiais de Impacto Urbano, avaliando seus efeitos e impactos na cidade entre os anos de 2010 e 2019. A análises realizadas a partir das dimensões normativa, urbanística, espacial e econômica dos P.E., permitiram compreender o funcionamento do instrumento e seus impactos na cidade construída, bem como elaborar sugestões para a revisão do Plano Diretor.

Inicialmente saudado como um instrumento capaz de gerar a necessária flexibilização de normas e padrões urbanísticos para análise de casos particulares e para viabilização de projetos urbanos, os Projetos Especiais passaram a ser largamente utilizados sobretudo, por empreendedores privados, somando mais de 90 projetos em um período de 10 anos. Se num primeiro momento o dispositivo apresentou-se como possível recurso para a realização de projetos pontuais, onde de fato, a necessidade do projeto justificaria a flexibilização das normas urbanísticas, a pesquisa mostrou que os P.E. tornaram-se regra na realização de grandes projetos urbanos em Porto Alegre, colocando todas as regiões da cidade ao dispor dos empreendedores privados, desconsiderando aparentemente vocações e questões históricas, urbanas e ambientais.

A espacialização dos P.E.2 sobre o modelo de desenvolvimento espacial constante no Plano Diretor evidenciou a concentração destes projetos nas áreas com maior infraestrutura e já consolidadas da cidade, ao passo que áreas demarcadas pelo Plano como corredores de centralidade, de produção ou agroindustrial, onde haveria interesse na expansão da infraestrutura urbana, receberam poucos ou nenhum P.E.2. Tal constatação sugere que o modelo espacial não balizou a escolha de locais para a implementação dos projetos pesquisados, resultando na contradição de um instrumento urbanístico que, apesar de parte integrante do Plano Diretor, não tem contribuído para consolidar as estratégias espaciais nele propostas. Esta situação, acredita-se, é decorrente da ausência de efetivação de uma proposta de gestão aliada ao discurso programático do PDDUA. 
A distribuição espacial dos P.E.2 em relação à renda média dos domicílios em Porto Alegre, indicou maior concentração de projetos justamente nos bairros onde a renda média por domicílio é mais alta, corroborando a hipótese aqui sustentada de que tais projetos reforçam a segregação socioespacial na cidade ao investir em áreas já densificadas, com boa infraestrutura urbana e valor do solo elevado, resultando em empreendimentos com valores finais altos e direcionados a um público bastante seleto de maior poder aquisitivo. Este cenário indica que os P.E.2 reforçam o padrão excludente de ocupação do solo que historicamente pode-se observar no espaço urbano capitalista.

Os P.E.2 também parecem reforçar a segregação espacial em algumas áreas de menor renda média domiciliar, como foi possível observar na zona sul da cidade, na já citada Avenida Edgar Pires de Castro, onde os empreendimentos voltados para as classes de menor poder aquisitivo se caracterizaram por valores finais mais baixos, em áreas com pouca infraestrutura urbana e afastadas das áreas centrais. Nestes casos, muitas vezes os empreendimentos sobrecarregam a infraestrutura urbana preexistente e não qualificam as áreas contempladas pelos projetos, mantendo-as na condição de regiões periféricas da cidade, tal qual já existiam antes da realização dos projetos.

A pesquisa também revelou que $47 \%$ dos projetos aprovados foram para uso residencial ou uso misto, indicando que o instrumento foi utilizado, principalmente, para a construção de condomínios residenciais de grande porte. Neste sentido, ressalta-se que a utilização de um instrumento de flexibilização de regime urbanístico para projetos residenciais em áreas que já dispunham de regime urbanístico prévio, indica a consolidação do planejamento flexível em Porto Alegre, ao privilegiar a negociação caso a caso em detrimento da regra majoritária. Embora o PDDUA permita exceções por meio deste instrumento urbanístico, isto não deveria significar que os Projetos Especiais passem a ter protagonismo na urbanização da cidade ou que regiões não preparadas em termos de infraestrutura sejam ocupadas por P.E.2 em série.

Também foi possível perceber, ao longo do trabalho, que as obrigações e "contrapartidas" estabelecidas aos empreendedores individuais não são claras nem facilmente verificáveis, perdendo accountability, isto é, transparência e controle público. Naquelas obrigações claramente identificadas, foi possível observar a ênfase no desenvolvimento de projetos viários, em sua maioria para beneficiar o próprio empreendimento, justificadas com amparo 
em estudo de tráfego e cumprindo função mitigadora de impactos negativos. É também válido ressaltar que a altíssima porcentagem de obrigações relativas à construção de vias denota uma concepção de desenvolvimento urbano ainda pautada no automóvel, concepção está passível de questionamentos atualmente.

Como impactos diretos dos projetos especiais realizados ao longo de dez anos, tem-se uma cidade mais cara e mais densa nas áreas já consolidadas, e com maior dependência do automóvel, uma vez que as obrigações se concentram no desenvolvimento de projetos viários. Ao mesmo tempo, tem-se uma cidade mais excludente ao relegar para as classes de menor poder aquisitivo, áreas da cidade com menor infraestrutura e não qualificá-las de maneira adequada. Em termos de planejamento urbano, a utilização frequente do instrumento P.E. denota a institucionalização do planejamento flexível onde renuncia-se ao planejamento de longo prazo em detrimento do projeto urbano individual.

Ainda que tenha havido ampla proposição de estratégias, diretrizes, instrumentos urbanísticos e modelos de desenvolvimento espacial durante a elaboração do PDDUA, entende-se que esta produção teórica não foi acompanhada pelo reposicionamento da Prefeitura Municipal como agente articulador e promotor de estratégias de produção de cidade, o que exigiria investimentos para articulação de setores da PMPA, constante levantamento e produção de dados sobre o desenvolvimento urbano, capacitação de equipes técnicas para operacionalização destas funções, etc. Como resultado, verifica-se um plano-discurso cujas diretrizes espaciais têm apresentado baixa efetividade.

Como sugestões deste trabalho, que podem contribuir para o atual processo de revisão do PDDUA, propõe-se:

- A construção de uma proposta de gestão e gerenciamento do modelo espacial, com o Município como agente articulador de estratégias de produção de cidade e correspondentes investimentos para a efetivação desta gestão.

- A não utilização do instrumento P.E.2 para projetos de parcelamento do solo, pois projetos desta natureza possuem grande potencial para alteração de densidades nas diferentes regiões da cidade, podendo provocar grandes impactos em termos de infraestrutura urbana, com potencial aumento de tarifas e perda de qualidade dos serviços públicos. 
- A reavaliação de critérios para a inclusão de empreendimentos residenciais como Projetos Especiais, uma vez que a flexibilização de padrões para a construção de grandes condomínios vem sendo a principal utilização deste instrumento.

- A explicitação em Portal de Internet da PMPA das contrapartidas, compensações e medidas mitigatórias assumidas pelos empreendedores privados e seu status de execução, como forma de conferir maior transparência a esses retornos sociais dos empreendimentos.

- A explicitação em normas cogentes da diferenciação e da natureza das contrapartidas e das medidas mitigadoras e compensatórias de impactos urbanísticos e ambientais, de tal forma a garantir que os recursos obtidos pela flexibilização do regime urbanístico sejam investidos, consoante previsão do art. 26 do Estatuto da Cidade, pois detectou-se confusão conceitual entre os termos, o que compromete a sua efetiva exigência e, consequentemente, a justa distribuição dos ônus e benefícios da urbanização.

\section{Referências Bibliográficas}

AGUIRRE, Ana. O instrumento de Projetos Especiais no PDDUA de Porto Alegre: aplicações e impactos na dinâmica da cidade repercussões dos P.E.s na implantação do modelo espacial de desenvolvimento urbano. In: XXXI Salão de Iniciação Científica da Universidade Federal do Rio Grande do Sul (UFRGS). Porto Alegre, 2019.

CARDOSO, Isabel Moraes (coord.). A nova lei do solo. Análise comparativa das leis de solo em países europeus. Estudo de enquadramento para a preparação da Nova Lei do Solo. Ministério do Ambiente e do Ordenamento do Território. DGTU 8/2011. Lisboa, 2011.

CASTELLS, Manuel e BORJA, Jordi. As cidades como atores políticos, In: Novos Estudos. CEBRAP, n. 45, julho 1996, pp. 152-166. ISSN 0101-3300

COMPASS - Comparative Analysis of Territorial Governance and Spatial Planning Systems in Europe, Outubro de 2018. European Territorial Observatory Network. Disponível em <https://www.espon.eu/programme/espon/espon-2020-cooperation-programme>, acesso em 11 de março de 2019.

DARDOT, Pierre e LAVAL, Christian. A nova razão do mundo: ensaio sobre a sociedade neoliberal. 1ạ Ed., São Paulo: Boitempo, 2016.

European Commission. The EU Compendium of spatial planning systems and policies. Luxembourg: Office for Official Publications of the European Communities, 1997. ISBN 92-287-9752-X. Disponível em: <https://www.espon.eu/programme/espon/espon-2020-cooperation-programme>, acesso em 11 de março de 2019.

FAGUNDES, Júlia Ribes. Projetos Especiais em Porto Alegre: Análise do instrumento urbanístico e sua gestão no contexto do planejamento flexível. Projeto de tese apresentado ao Programa de Pós-graduação em Geografia como requisito para o exame de Qualificação na Universidade Federal do Rio Grande do Sul. Porto Alegre, 2019.

GIELEN, Demetrio Muñoz. Quién paga los objetivos públicos en el urbanismo en Inglaterra, Los Países Bajos y la Comunidad Autónoma Valenciana? In: Architecture, City and Environment - ACE, año IV, n. 11, octubre, 2009, pp.19-43. ISSN: 1886-480 
. Capturing value increase in urban redevelopment. A study of how the economic value increase in urban redevelopment can be used to finance the necessary public infrastructure and other facilities. Leiden: Sidestone Press, 2010. ISBN 978-90-8890-059-4

GIELEN, Demetrio Muñoz \& TASAN-KOK, Tuna. Flexibility in Planning and the consequences for public-value capturing in UK, Spain and the Netherlands. In European Planning Studies, vol. 18, n. 7, July 2010. Routledge Taylor \& Francis Group, pp. 1097-1131. ISSN 0965-4313. DOI: 10.1080/09654311003744191

GIELEN, Demetrio Muñoz \& LENFERINK, Sander (2018). The role of negotiated developer obligations in financing large public infrastructure after the economic crisis in the Netherlandes. In European Planning Studies, 26:4, 768-791, DOI: 10.1080/09654313.2018.1425376.

GÜELL, José Miguel Fernández. Estrategias de ciudades. In: Innovaciones tecnológicas con aplicación en el ámbito local. Fundación Cotec para la Innovación Tecnológica, Madrid, España, 2008, pp. 31-54. ISBN: 978-8495336-83-5

HEALEY, Patsy; KHAKEE, Abdl; MOTTE, Alain; and NEEDHAM, Barrie. European developments in strategic spatial planning. In: European Planning Studies, 1999, 7:3, 339-355. https://doi.org/10.1080/09654319908720522

HARVEY, David. Condição pós-moderna. Uma pesquisa sobre as origens da mudança cultural. Trad. Adail Ubirajara Sobral e Maria Stela Gonçalves, São Paulo: Edições Loyola, 1999, p. 140. ISBN 85-15-00679-0

JULIO, Roger de Oliveira Borges. O déficit de cidade e a expansão urbana e imobiliária na cidade rururbana de Porto Alegre. In: XXX Salão de Iniciação Científica - SIC, Universidade Federal do Rio Grande do Sul. Porto Alegre, 2018.

LEAL, Suely Ribeiro. A retração da acumulação urbana nas cidades brasileiras: a crise do Estado diante da crise do mercado. Cadernos Metrópole, São Paulo, v. 19, n. 39, maio/ago 2017, pp. 379-406. ISSN 2236-9996

LEVY, John. Contemporary Urban Planning, 4th Edition.New Jersey: Prentice Hall, 1997. ISBN 9781317349167 1317349164

MAYORAL, León Calvo. El discurso urbanístico en los años ochenta; Análisis político e ideológico de los paradigmas hegemónicos en el urbanismo español y sus condiciones de aparición. Tesis Doctoral. Universidad Complutense de Madrid. Facultad de Ciencias Políticas y Sociologia. Madrid, 1995

NADIN, Vicent and STEAD, Dominic. European Spatial Planning Systems, social models and learning. In The Planning Review, 2008, v. 44 (172), 35-47. DOI: 10.1080/02513625.2008.10557001

PÉREZ, Jorge H. 2o PDDUA. A Necessária Releitura da Cidade. Publicação da Secretaria do Planejamento Municipal de Porto Alegre, Prefeitura de Porto Alegre, março de 1998.

PORTO ALEGRE - Prefeitura Municipal - Secretaria de Meio Ambiente e da Sustentabilidade. Guia de Consulta: Regime Urbanístico. Versão Janeiro/2019. Porto Alegre, SMAM. P. 13. Disponível em: http://lproweb.procempa.com.br/pmpa/prefpoa/spm/usu_doc/guia_pddua.pdf . Acesso em: nov. 2019.

PORTO ALEGRE - Prefeitura Municipal - Secretaria de Planejamento Municipal. Plano Diretor de Desenvolvimento Urbano e Ambiental - PDDUA (L.C. no 434/ 1999, atualizada e compilada até a L.C. no 667/ 2011, incluindo a L.C. 646/ 2010). Porto Alegre, SPM.

RIVOLIN. Umberto Janin. Conforming and performing planning systems in Europe: An unbearable cohabitation. In: Planning, Practice \& Research, 23:2, 167-186, 2008. DOI 10.1080/02697450802327081

UTZIG Elisa. O instrumento de Projetos Especiais no PDDUA de Porto Alegre: aplicações e impactos na dinâmica da cidade. Uma análise das contrapartidas, medidas compensatórias e medidas mitigatórias. In: XXXI Salão de Iniciação Científica da Universidade Federal do Rio Grande do Sul (UFRGS). Porto Alegre, 2019.

VAINER, Carlos (org et al). Os Megaeventos e a cidade: perspectivas críticas. Rio de Janeiro: Letra Capital, 2016 p. 19 - 46. ISBN 978-85-7785-467-7

VAINER, Carlos.Pátria, empresa e mercadoria: notas sobre a estratégia discursiva do Planejamento Estratégico Urbano. In ARANTES, O; VAINER, C; MARICATO, E. A cidade do pensamento único: desmanchando consensos, 3a. Ed, Petrópolis: Editora Vozes, 2002. ISBN 978-85-326-2384-3 
VAN DER VEEN, Menno. Contracting for better place. A relational analysis of development agreements in urban development projects. Amsterdam: IOS Press BV, 2009. ISBN 978-1-60750-005-6

VIZZOTTO, Andrea Teichmann. A efetividade da justa distribuição do ônus do processo de urbanização por meio da recuperação de mais valias urbanas: Estudo de caso do Shopping Center Iguatemi em Porto Alegre, 1983-2016. Tese de Doutorado em Planejamento Urbano e Regional. Faculdade de Arquitetura. UFRGS, Porto Alegre, abril de 2018. 